\title{
Interspecific divergence in foliar nutrient dynamics and stem growth in a temperate forest in response to chronic nitrogen inputs
}

\author{
Jeffrey D. May, Sarah Beth Burdette, Frank S. Gilliam, and Mary Beth Adams
}

\begin{abstract}
We studied the effects of excessive nitrogen $(\mathrm{N})$ fertilization on foliar nutrient dynamics and stem growth in three important tree species in a mixed-deciduous forest. Stem diameter growth, foliar N concentrations, nitrogenphosphorus (N/P) ratios, and nutrient resorption were determined for Acer rubrum L. (ACRU), Liriodendron tulipifera L. (LITU), and Prunus serotina Ehrh. (PRSE) on two 30-year-old watersheds at the Fernow Experimental Forest, West Virginia, USA: WS3, fertilized annually with $35 \mathrm{~kg}$ ammonium sulfate $\cdot \mathrm{ha}^{-1}$ since 1989, and WS7, an untreated control watershed. In an earlier (1992) study, foliar N concentrations of all three species averaged $11 \%$ higher in WS3 than in WS7. By 2000, that was no longer the case for any species; indeed N in ACRU leaves was $13 \%$ lower in WS3 that year. N/P ratios were elevated in WS3 only in PRSE in 1992 and in both ACRU and PRSE in 1997, but by 2001, mean N/P for all three species was lower in WS3. N resorption efficiencies were $30 \%$ lower in WS3 in ACRU and PRSE, but not in LITU. Stem diameter growth in WS3 was 55\% lower in ACRU and 30\% lower in LITU and PRSE compared with that in WS7. Results may indicate declining growth vigor in ACRU and, to a lesser extent, PRSE and LITU in the fertilized watershed. Observed interspecific differences in growth and plant nutrition responses suggest eventual changes in species composition under increasing $\mathrm{N}$ saturation.
\end{abstract}

Résumé : Les auteurs ont étudié les effets d'une fertilisation excessive en azote (N) sur la dynamique des nutriments dans les feuilles et la croissance de la tige de trois espèces d'arbres importantes dans une forêt feuillue mélangée. La croissance en diamètre de la tige, les concentrations de N, les rapports azote-phosphore (N/P) dans les feuilles et la résorption des nutriments ont été mesurées pour Acer rubrum L. (ACRU), Liriodendron tulipifera L. (LITU) et Prunus serotina Ehrh. (PRSE) dans deux bassins versants de 30 ans à la forêt expérimentale de Fernow en Virginie de l'Ouest (É.-U.) : WS3 - bassin fertilisé annuellement avec $35 \mathrm{~kg} \cdot \mathrm{ha}^{-1}$ de sulfate d'ammonium depuis 1989 et WS7 - bassin versant non traité utilisé comme témoin. Dans une étude antérieure, la concentration de $\mathrm{N}$ dans les feuilles des trois espèces était en moyenne $11 \%$ plus élevée dans WS3 que dans WS7. En 2000, ce n'était plus le cas pour aucune des espèces; cette année là en effet, la concentration de $\mathrm{N}$ dans les feuilles d'ACRU était $13 \%$ plus faible dans WS3. Le rapport N/P était élevé dans WS3 seulement chez PRSE en 1992 et chez ACRU et PRSE en 1997. Mais à partir de 2001 le rapport moyen N/P pour les trois espèces d'arbres était plus faible dans WS3. L'efficacité de résorption de N était $30 \%$ plus faible dans WS3 chez ACRU et PRSE mais pas chez LITU. La croissance en diamètre de la tige dans WS3 était $55 \%$ plus faible chez ACRU et $30 \%$ plus faible chez LITU et PRSE comparativement à WS7. Les résultats pourraient être l'indice d'une croissance moins vigoureuse chez ACRU et, jusqu'à un certain point, chez PRSE et LITU dans le bassin soumis à une fertilisation. Les différences qui ont été observées dans le comportement de la croissance et de la nutrition annoncent d'éventuels changements dans la composition en espèces avec l'augmentation de la saturation en $\mathrm{N}$.

[Traduit par la Rédaction]

\section{Introduction}

Although atmospheric deposition of nitrogen $(\mathrm{N})$ often has an initial fertilizing effect on temperate deciduous forests, chronic elevated deposition may lead to $\mathrm{N}$ saturation, wherein rates of input exceed the demands of the biota (Aber et al. 1998; Fenn et al. 1998; Matson et al. 2002).
Ecosystem-level responses to $\mathrm{N}$ saturation have been well documented (e.g., Tamm et al. 1995; Gilliam et al. 1996; Peterjohn et al. 1996; Edwards et al. 2002; Fernandez et al. 2003), but there has been little study of the effects of excessive $\mathrm{N}$ deposition on internal plant nutrient dynamics or the potential for plants to modify those effects through variation in the disposition and use efficiency of individual nutrients.

Received 6 January 2005. Accepted 26 January 2005. Published on the NRC Research Press Web site at http://cjfr.nrc.ca on 18 May 2005.

J.D. May, ${ }^{1}$ S.B. Burdette, ${ }^{2}$ and F.S. Gilliam. Department of Biological Sciences, Marshall University, Huntington, WV 25755 , USA.

M.B. Adams. USDA Forest Service, Timber and Watershed Laboratory Parsons, WV 26287, USA.

${ }^{1}$ Corresponding author (e-mail: may @marshall.edu)

${ }^{2}$ Present address: Potesta \& Associates, 2300 MacCorkle Avenue SE, Charleston, WV 25304, USA. 
One important mechanism of internal nutrient regulation in deciduous trees is nutrient resorption: the reclamation of foliar nutrients into storage tissues that takes place during leaf senescence in the fall (Killingbeck 1996). Many species resorb $60 \%-80 \%$ of the $\mathrm{N}$ and phosphorus $(\mathrm{P})$ invested in foliage (Chapin and Kedrowski 1983), accounting for a third or more of $\mathrm{N}$ and $\mathrm{P}$ used by temperate forest trees during the growing season (Ryan and Bormann 1982; Lal et al. 2001). Because resorption responds to internal nutrient status as well as to a variety of environmental factors (May and Killingbeck 1995), it provides a mechanism by which plants might buffer nutritional changes induced by $\mathrm{N}$ saturation of the soil. For example, excess $\mathrm{N}$ uptake could result in decreasing $\mathrm{N}$ resorption efficiency, helping to maintain a rough balance in internal nutrient concentrations.

We took advantage of an ongoing long-term watershed level $\mathrm{N}$-fertilization experiment to assess the impact of excessive $\mathrm{N}$ fertilization on foliar nutrient dynamics and stem growth in ecologically and economically important tree species in a mid-Appalachian mixed-deciduous forest. Specifically, we addressed the following central questions: ( $i$ ) What is the effect of chronic excess $\mathrm{N}$ inputs on foliar $\mathrm{N}$ concentration and resorption? (ii) How are foliar $\mathrm{N}$ concentration and N/P ratio related to soil $\mathrm{N}$ dynamics in a highly $\mathrm{N}$-saturated system? (iii) After more than a decade of $\mathrm{N}$ fertilization, has there been a measurable effect on stem growth?

\section{Materials and methods}

The study was conducted at the Fernow Experimental Forest (FEF) near Parsons, West Virginia, USA $\left(39^{\circ} 04^{\prime} \mathrm{N}\right.$, $79^{\circ} 41^{\prime} \mathrm{W}$ ). Two watersheds were used: watershed 7 (WS7; $24 \mathrm{ha}$ ) served as the control watershed and has received no treatments since being clear-cut in 1969. The vegetation on WS7 is dominated by even-aged, second-growth, mixedhardwood forest. Watershed 3 (WS3; 34 ha) is similar in age and composition, but has received three aerial applications of ammonium sulfate annually since 1989. Applications have been apportioned as $7.1 \mathrm{~kg} \mathrm{~N} \cdot \mathrm{ha}^{-1}$ in early spring and again in late autumn, and $21.2 \mathrm{~kg} \mathrm{~N} \cdot \mathrm{ha}^{-1}$ in July, for a total annual addition of $35 \mathrm{~kg} \mathrm{~N} \cdot \mathrm{ha}^{-1}$, about twice the ambient input from atmospheric deposition (Gilliam et al. 2001).

Foliage of three important tree species, red maple (Acer rubrum L.: ACRU), tulip poplar (Liriodendron tulipifera L.: LITU), and black cherry (Prunus serotina Ehrh.: PRSE), was sampled in 1992, 1997, and 2000-2001. In 1992 and 1997 (3 and 8 years after $N$ treatments began), green leaves were collected from 20 and 5 individuals, respectively, of each species on each watershed. Nutrient analyses for those sample years were carried out at the Timber and Watershed Lab, Northeastern Research Station, USDA Forest Service, Parsons, West Virginia. In 2000-2001 (11-12 years after N treatments began), green leaves were collected in late summer from branches shot from tree crowns of three individuals of each species using a 12-gauge shotgun and Nos. 2 or 4 stainless steel shot. To estimate nutrient resorption efficiencies, abscised leaves were collected from the ground as close as possible to the trees that had been sampled prior to senescence. This inevitably resulted in samples that were composed of senesced leaves from more than one individual of the same species; however, by sampling consistently close to the marked trees, we attempted to maintain some consistency in soil influences on plant nutrient dynamics. There was at least $120 \mathrm{~m}$ between sampled trees of the same species. Freshly fallen leaves were collected weekly during the period of senescence to minimize their exposure to leaching by rain.

Leaf area of each sample was measured using a LiCor LI-3000 area meter. Leaves were then dried at $60{ }^{\circ} \mathrm{C}$ to constant mass and ground in a Wiley mill to pass a 40-mesh screen. Subsamples $(0.25 \mathrm{~g})$ of the ground material were digested in a solution of sulfuric acid, potassium sulfate, and mercuric oxide (EPA method 351.2). Total Kjeldahl $\mathrm{N}$ and phosphate $\mathrm{P}$ were determined in the digested samples with a Bran+Luebbe TrAAcs 2000 automated wet-chemistry system. Because overall leaf tissue mass often changes substantially during senescence, $\mathrm{N}$ resorption efficiencies reported herein were based on changes in nutrient content per unit area for presenescent and senesced leaves. Resorption efficiency was determined as [(green - senesced $) /$ green $] \times 100 \%$, where "green" represents the $\mathrm{N}$ level in presenescent green leaves (milligrams $\mathrm{N}$ per square centimetre of leaf tissue), and "senesced" represents the level in senesced leaves.

Resorption proficiency may be more sensitive to nutrient availability than is resorption efficiency (Killingbeck 1996; Van Heerwaarden et al. 2003). Resorption proficiency is defined as the foliar concentration to which the plant is able to reduce a given nutrient during senescence. It is represented simply as the nutrient concentration in senesced leaves, a higher concentration thus reflecting less proficient resorption. While resorption efficiency depends partly on proficiency, it also is affected by a variety of factors (e.g., weather, luxury uptake) that influence green tissue nutrient content. Thus, these measures are not merely two ways of looking at the same thing.

Stem diameter at breast height (DBH at $1.5 \mathrm{~m}$ ) was measured with a diameter tape for each of the study trees in Fall 1999 and again in 2001. Mineral soil was sampled to a depth of $5 \mathrm{~cm}, 2 \mathrm{~m}$ from the trunk of each study tree in Fall 2001. Subsamples from four sides of the trunk were bulked into two Whirl-Pak plastic bags per tree. On return to the lab at Marshall University, one bag was incubated in the laboratory at $25{ }^{\circ} \mathrm{C}$ for 4 weeks; the other bag was refrigerated during that period to minimize soil microbial transformations. The latter sample was considered to be unincubated, and was intended to reflect field $\mathrm{N}$ concentrations on the date of sampling, such that differences between bags indicate $\mathrm{N}$ transformations during incubation at $25^{\circ} \mathrm{C}$. $\mathrm{N}$ was extracted from moist soils using $1 \mathrm{~mol} \cdot \mathrm{L}^{-1} \mathrm{KCl}$ at an extract-soil ratio of 10:1 ( $/ / m)$, and analyzed for $\mathrm{N}$ as nitrate $\left(\mathrm{NO}_{3}-\mathrm{N}\right)$ and ammonium $\left(\mathrm{NH}_{4}-\mathrm{N}\right)$ using a Bran+Luebbe TrAAcs 2000 continuous-flow wet-chemistry system. Soil moisture content was determined gravimetrically by drying separate $30-\mathrm{g}$ subsamples. After adjusting for soil moisture, inorganic soil $\mathrm{N}$ in nitrate and ammonium form $\left(\mathrm{NO}_{3}-\mathrm{N}\right.$ and $\mathrm{NH}_{4}-\mathrm{N}$, respectively) was calculated in milligrams $\mathrm{N}$ per kilogram dry mass of soil.

Differences in N concentration between incubated ("post") and unincubated ("pre") soil samples were used to calculate monthly nitrification and $\mathrm{N}$ mineralization rates, as follows: 
Table 1. Mean soil N pools and fluxes for control (WS7) and Nfertilized (WS3) watersheds at the Fernow Experimental Forest, Parsons, West Virginia, in 2001.

\begin{tabular}{|c|c|c|c|}
\hline & \multicolumn{2}{|l|}{ Watershed } & \multirow[b]{2}{*}{$p$ value } \\
\hline & WS7 & WS3 & \\
\hline $\mathrm{NO}_{3}-\mathrm{N}\left(\mathrm{mg} \cdot \mathrm{kg}^{-1}\right)$ & $5.5(1.2)$ & $11.8(2.5)$ & 0.042 \\
\hline $\mathrm{NH}_{4}-\mathrm{N}\left(\mathrm{mg} \cdot \mathrm{kg}^{-1}\right)$ & $8.3(0.7)$ & $5.3(1.4)$ & 0.084 \\
\hline Total inorganic $\mathrm{N}\left(\mathrm{mg} \cdot \mathrm{kg}^{-1}\right)$ & $13.8(0.9)$ & $17.1(2.3)$ & 0.211 \\
\hline Nitrification $\left(\mathrm{mg} \cdot \mathrm{kg}^{-1} \cdot\right.$ month $\left.^{-1}\right)$ & $52.9(6.1)$ & $48.6(8.3)$ & 0.682 \\
\hline Mineralization $\left(\mathrm{mg} \cdot \mathrm{kg}^{-1}\right)$ & $50.6(5.6)$ & $48.1(8.3)$ & 0.810 \\
\hline
\end{tabular}

Note: Fluxes were estimated using in vitro incubations at $25{ }^{\circ} \mathrm{C}$. Standard errors are in parentheses. For WS7 data, $N=8$ for $\mathrm{NH}_{4}-\mathrm{N}$, total inorganic N, and mineralization. For all other values $N=9$.

$$
\begin{gathered}
\text { Net nitrification }=\left[\mathrm{NO}_{3}-\mathrm{N}\right]_{\text {post }}-\left[\mathrm{NO}_{3}-\mathrm{N}\right]_{\text {pre }} \\
\text { Net N mineralization }=\left[\mathrm{NO}_{3}-\mathrm{N}+\left[\mathrm{NH}_{4}-\mathrm{N}\right]_{\text {post }}\right. \\
-\quad\left[\mathrm{NO}_{3}-\mathrm{N}+\mathrm{NH}_{4}-\mathrm{N}\right]_{\text {pre }}
\end{gathered}
$$

Soil N variables were compared with Student's $t$ test. Analysis of variance (ANOVA) was used for statistical comparisons of foliar nutrient concentrations, resorption, and stem growth between watersheds, among species, and among study years. For example, to compare foliar $\mathrm{N}$ concentrations between watersheds, ANOVA was performed for each year on $\mathrm{N}$ concentration in all three species in both watersheds. Correlations between pairs of factors were assessed using Pearson product-moment correlation analysis. All statistics were performed using SYSTAT (SYSTAT Software, Inc. 2004), and graphs were prepared in DeltaGraph (SPSS Inc. 2000).

The problem of pseudoreplication arises commonly in watershed-level studies. It is the watershed, rather than replicate tree or soil samples within watersheds, that represents the experimental unit (Hurlbert 1984; Gilliam et al. 1994). As a result, treatment effects evident in studies at this scale must be interpreted with that consideration in mind.

\section{Results and discussion}

\section{Soil N}

After more than a decade of fertilization, soil N in WS3 was only modestly different from the unfertilized control, WS7 (Table 1). Mean soil $\mathrm{NO}_{3}-\mathrm{N}$ concentration in WS3 was more than double that in WS7 ( $p=0.042$; Table 1), while $\mathrm{NH}_{4}-\mathrm{N}$ was lower in WS3 $(p=0.084)$. Mean inorganic $\mathrm{N}$ concentration (combined $\mathrm{NO}_{3}-\mathrm{N}$ and $\mathrm{NH}_{4}-\mathrm{N}$ ) was $24 \%$ greater in soils of WS3 than in those of WS7, but the difference was not statistically significant $(p=0.21)$. Mineralization and nitrification rates, as measured using in vitro incubations, did not differ in soils from the two watersheds.

Several previous studies (Stoddard 1994; Gilliam et al. 1996; Peterjohn et al. 1996) concluded that, in addition to WS3, which is the N-fertilized watershed, other watersheds at FEF are experiencing increasing levels of $\mathrm{N}$ saturation because of high levels of ambient atmospheric deposition. In comparison with our results, Gilliam et al. (2001) found similar levels of $\mathrm{N}$ in WS3 soils (total inorganic $\mathrm{N}=16.0 \mathrm{mg}$ $\mathrm{N} \cdot(\mathrm{kg} \mathrm{soil})^{-1}$ ) sampled in 1993-1995, but notably lower lev-
Fig. 1. Foliar $\mathrm{N}$ concentration as a function of soil $\mathrm{NO}_{3}-\mathrm{N}$ concentration for three tree species in control (WS7) and nitrogenfertilized (WS3) watersheds in 2001. Each point represents a single individual.
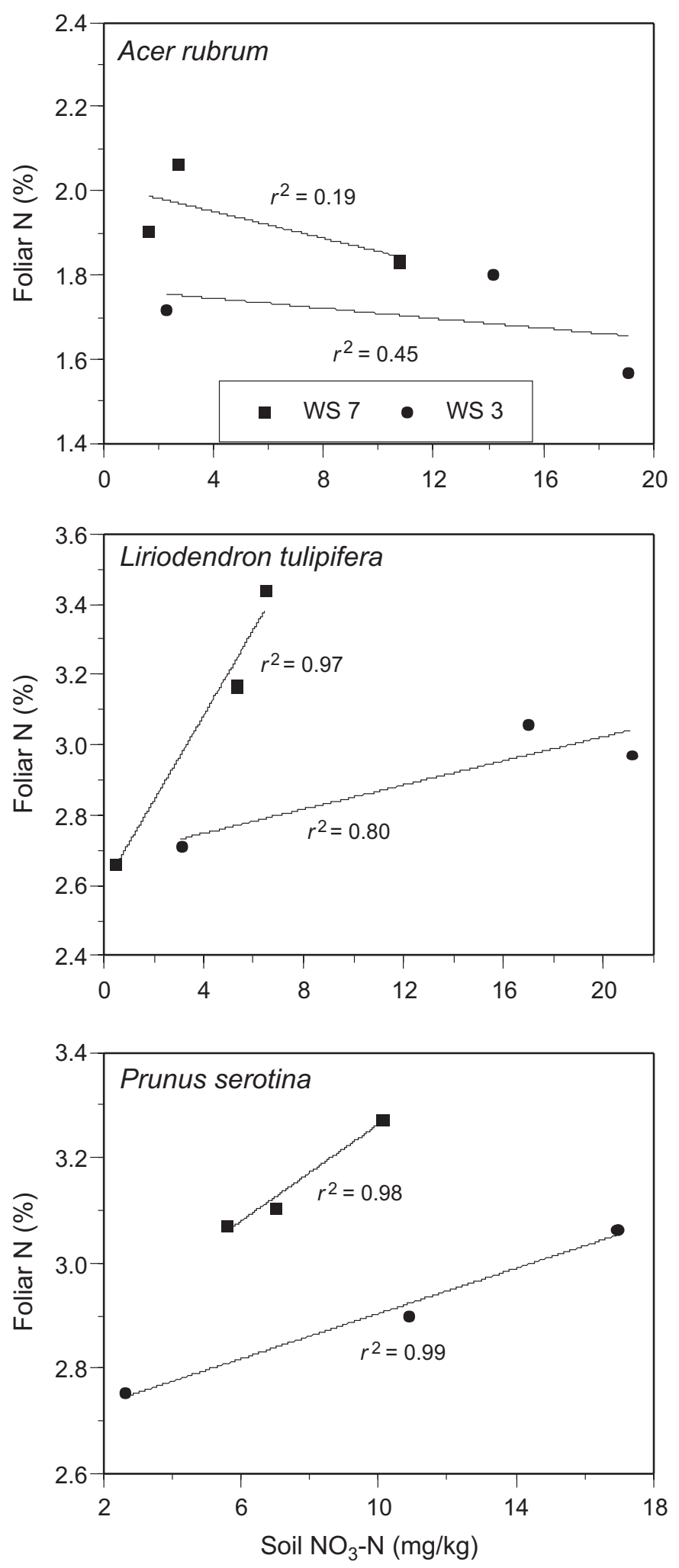
Fig. 2. Mean $\mathrm{N}$ concentration (left) and N/P ratio (right) in green leaves of three tree species in control (WS7, solid lines) and Nfertilized (WS3, broken lines) watersheds, 1992-2001. For each species and watershed, $N=20$ in $1992 ; N=5$ in $1997 ; N=3$ in 2000-2001. Error bars represent 1 SE of the mean.

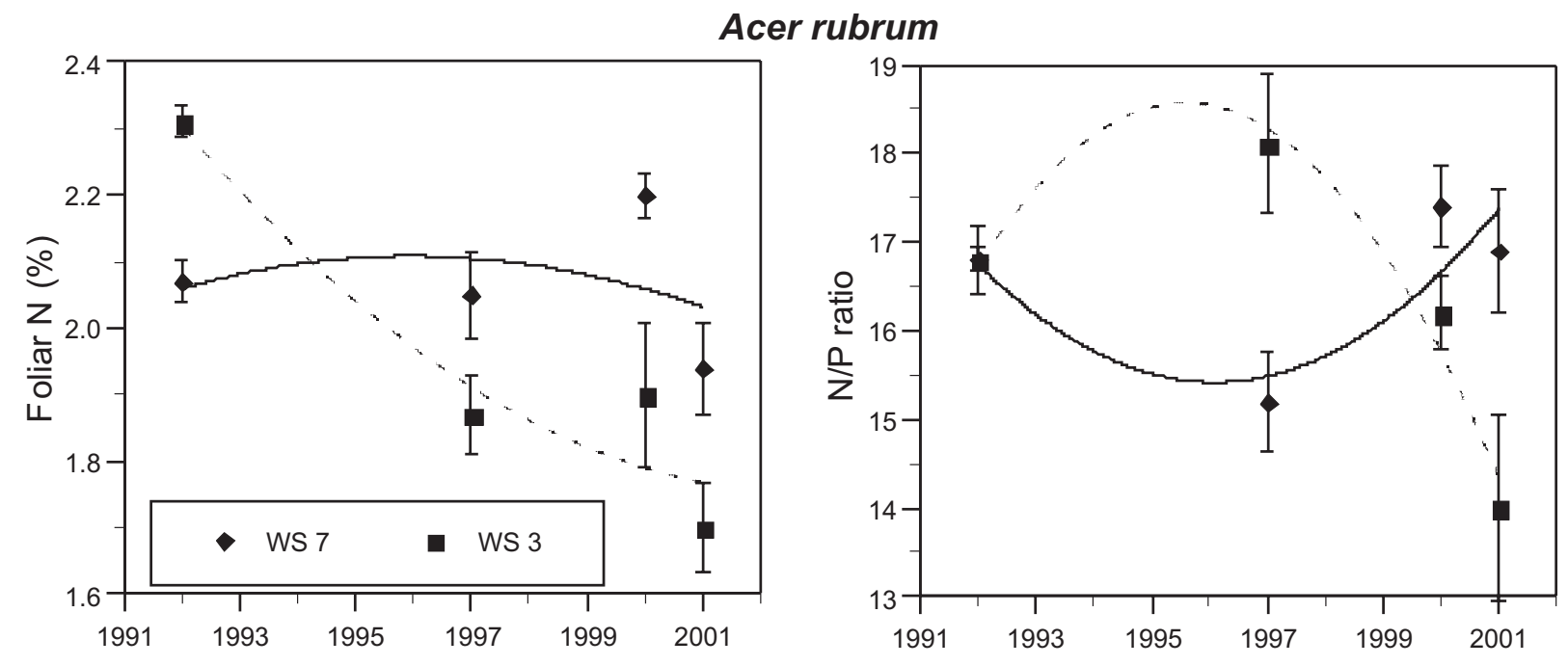

Liriodendron tulipifera
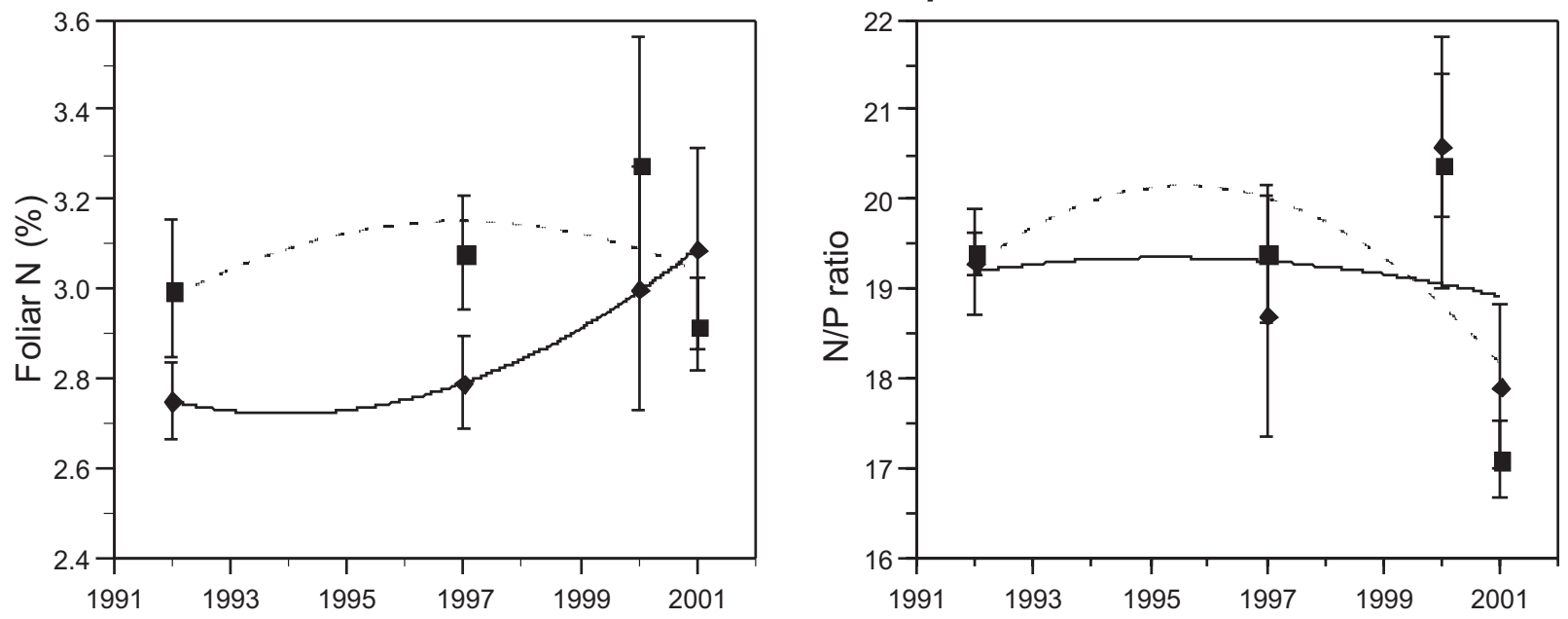

Prunus serotina
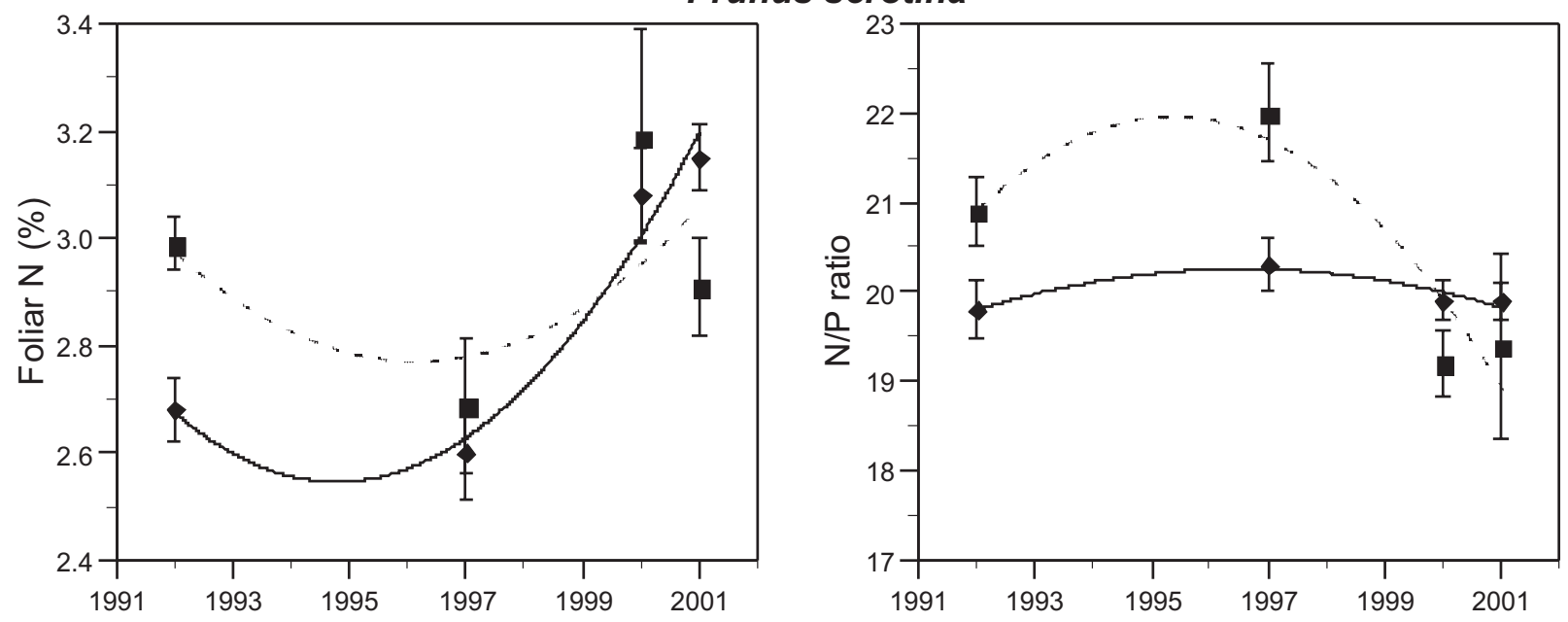
Fig. 3. Mean $\mathrm{N}$ resorption efficiency (top) and proficiency (bottom, represented as $\mathrm{N}$ concentration in senesced leaves) in three tree species in control (WS7) and N-fertilized (WS3) watersheds in 2000-2001. ACRU, Acer rubrum; LITU, Liriodendron tulipifera; PRSE, Prunus serotina. $N=3$ for each mean; error bars represent $1 \mathrm{SE}$ of the mean.
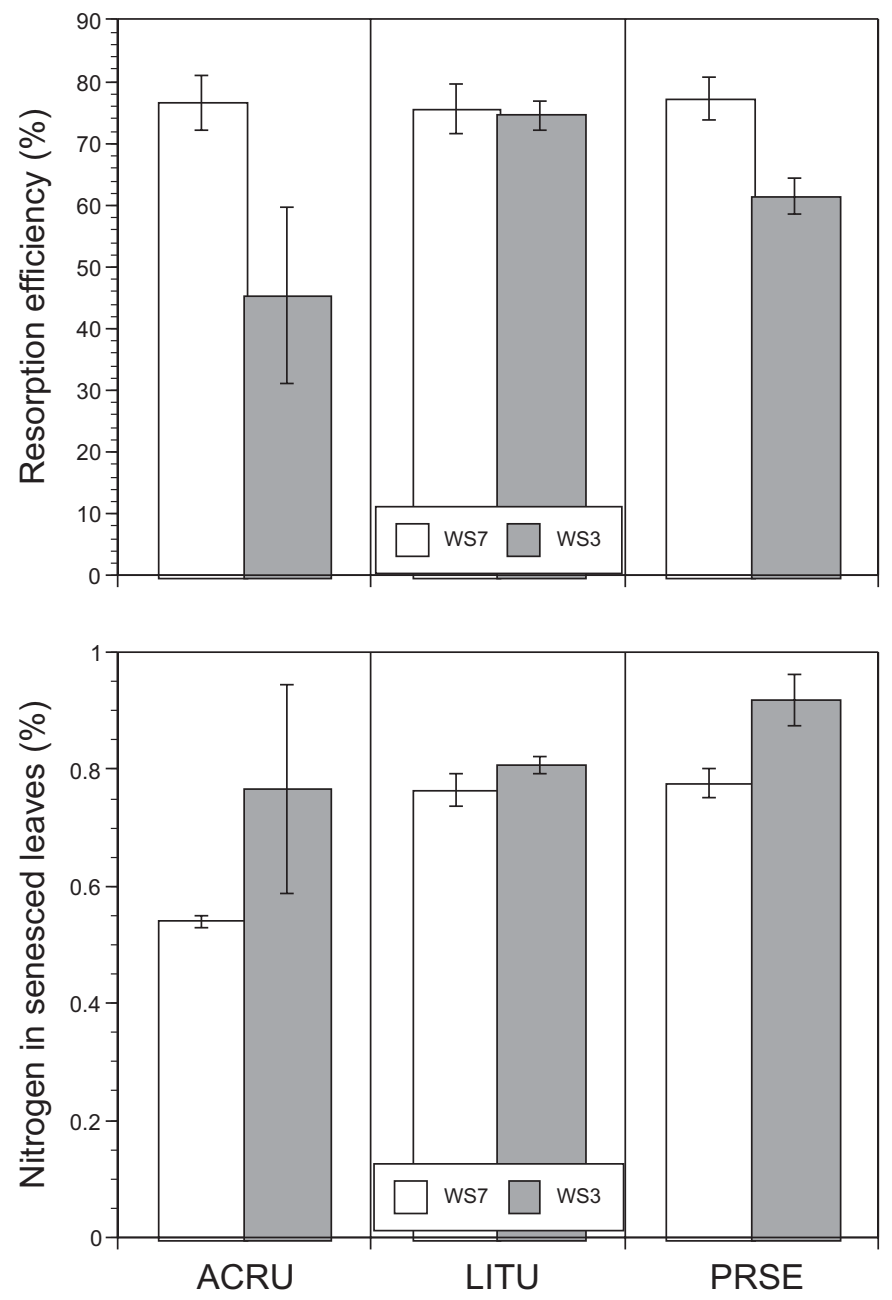

els in WS7 (10.3 $\left.\mathrm{mg} \mathrm{N} \cdot(\mathrm{kg} \mathrm{soil})^{-1}\right)$. The apparent trend toward convergence of soil N dynamics in WS7 with those of WS3 may suggest that ambient deposition is driving WS7 toward the level of extreme $\mathrm{N}$ saturation induced artificially in WS3.

\section{Foliar $\mathrm{N}$ and N/P ratios}

Plant nutrient responses in this study contrasted with those of previous studies (e.g., Schaberg et al. 1997; Hutchinson et al. 1998). Foliar N concentration of LITU and PRSE was positively correlated with soil $\mathrm{NO}_{3}-\mathrm{N}$ concentration in both watersheds (Fig. 1). The relationship was generally negative but not significant for ACRU. For all soil $\mathrm{NO}_{3}-\mathrm{N}$ values, foliar $\mathrm{N}$ concentration within each species was higher in WS7 than in the fertilized watershed (WS3), suggesting a disconnect between $\mathrm{N}$ availability and plant uptake capacity in WS3.

In 1992, average foliar $\mathrm{N}$ concentrations were about $11 \%$ higher $(p<0.0001$; ANOVA, by year) for all three species in WS3 relative to WS7 (Fig. 2). However, by 1997 this difference was no longer evident ( $p=0.42$; ANOVA). While there
Fig. 4. Mean stem diameter (DBH) growth over 2 years (19992001) in three tree species in control (WS7) and N-fertilized (WS3) watersheds. ACRU, Acer rubrum; LITU, Liriodendron tulipifera; PRSE, Prunus serotina. $N=3$ for each mean; error bars represent $1 \mathrm{SE}$ of the mean.

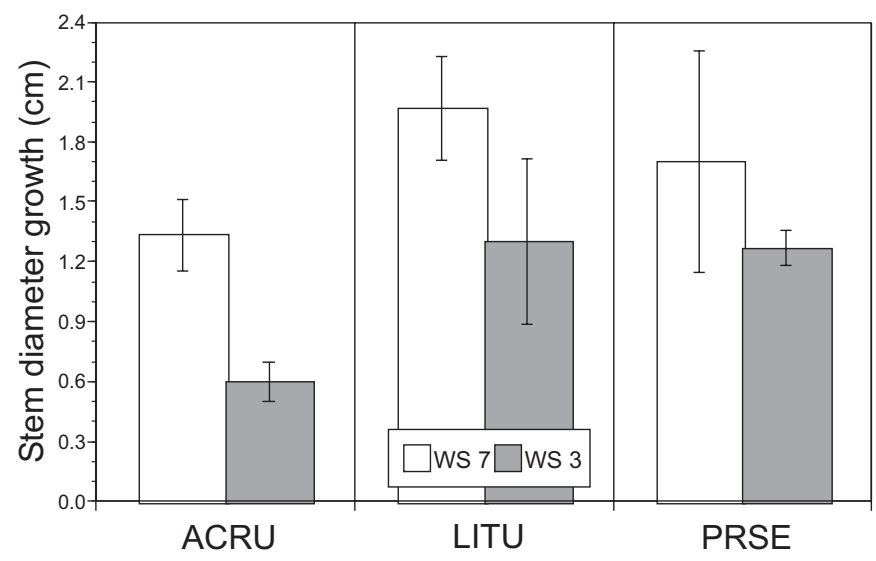

was little overall change in mean foliar N in WS3 for either LITU or PRSE, this was accompanied by increases in WS7 of $13 \%$ for LITU (NS, ANOVA) and $18 \%$ for PRSE ( $p=$ 0.016 , ANOVA) over the same time period. This may be further evidence of convergence in ecosystem function between these watersheds, as WS7 becomes increasingly $\mathrm{N}$ saturated because of ambient $\mathrm{N}$ loadings. Unlike the other species, $\mathrm{N}$ concentration in ACRU leaves declined by $26 \%$ in WS3 between 1992 and 2001 ( $p<0.0001$, ANOVA), but by just $6 \%$ in WS7 (NS, ANOVA).

Foliar N/P ratios have been used to assess relative $\mathrm{N}$ and $\mathrm{P}$ limitations in a variety of plants (Koerselman and Meuleman 1996; Tessier and Raynal 2003), and elevated $\mathrm{N} / \mathrm{P}$ ratios are often associated with regions of higher $\mathrm{N}$ deposition (Fenn et al. 1998). In this study, only PRSE exhibited higher N/P ratio in WS3 in 1992, after 3 years of fertilization (Fig. $2 ; p=0.030$, ANOVA). Five years later, the ratio was higher in WS3 for both ACRU (by $18.3 \% ; p=0.020$, ANOVA) and PRSE (by $8.3 \% ; p=0.026$, ANOVA). Subsequently, however, foliar N/P ratios declined significantly in both of those species ( $p<0.0001$ and 0.035 , respectively; ANOVA) in WS3, but did not change in WS7. By 2001, mean N/P ratio was higher for all three species ( $p=0.021$, ANOVA) in the control (WS7) than in the fertilized watershed (WS3); however, the N/P ratio in LITU showed little change overall in either watershed.

Although the overall pattern of N/P change in WS3 between 1992 and 2001 was similar for ACRU and PRSE, the cause of the change differed. In ACRU, a large drop in $\mathrm{N}$ concentration was accompanied by a smaller (13\%) decline in $\mathrm{P}$ concentration, whereas in PRSE, $\mathrm{P}$ concentration increased by $10 \%$ over this time period, while $\mathrm{N}$ did not change significantly. The N/P ratios of all three species in both watersheds $(15 \%-20 \%)$ are within the range that has been used to characterize $\mathrm{P}$ limitation in other ecosystems (Koerselman and Meuleman 1996; Tessier and Raynal 2003).

\section{Nutrient resorption}

Patterns of $\mathrm{N}$ resorption efficiency and proficiency for an individual tree were generally similar in 2000 and 2001; we 
Fig. 5. Stem diameter growth as a function of $\mathrm{N}$ resorption efficiency for three tree species in control (WS7) and N-fertilized (WS3) watersheds in 2001.
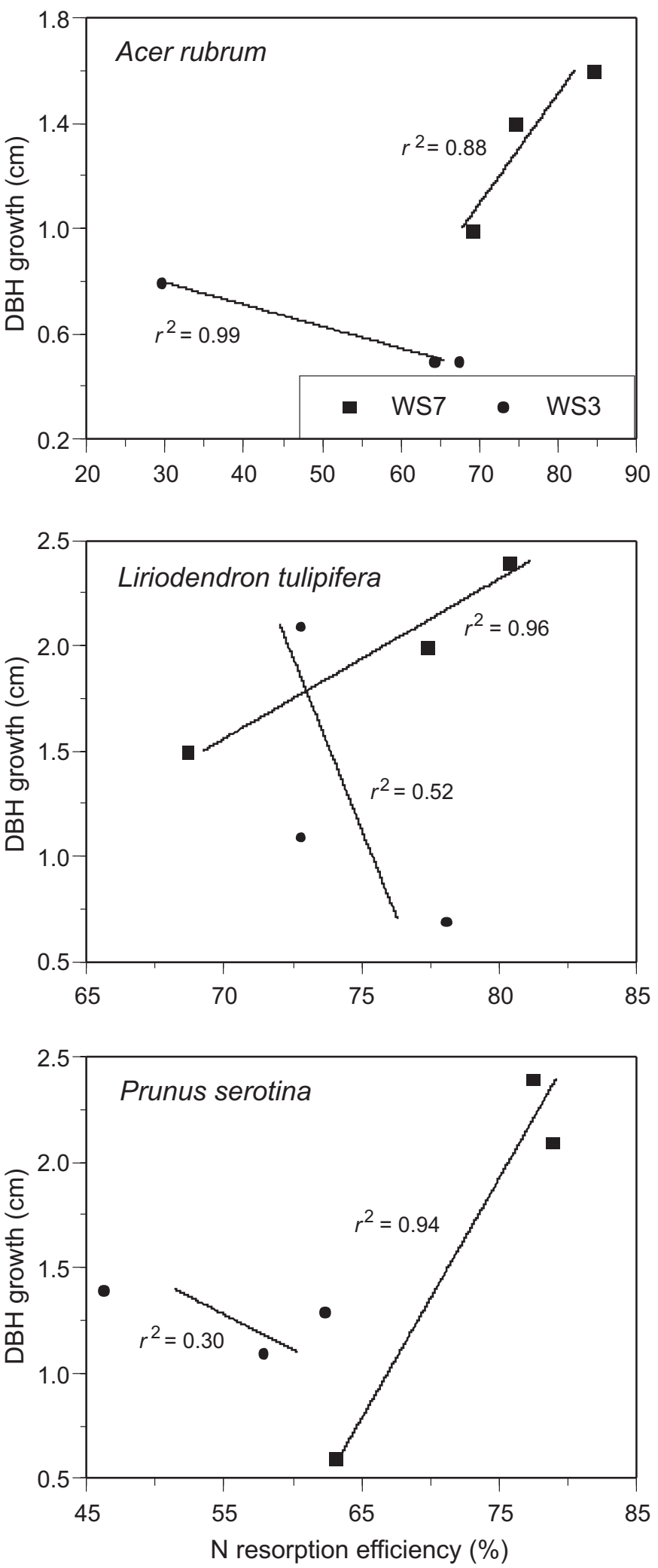

present analysis of the 2-year means for visual and statistical simplicity. In WS7, resorption efficiencies in all three species averaged $77 \%$ (Fig. 3, top), near the high end of the range of published values (Chapin and Kedrowski 1983). Average resorption efficiency was substantially lower in WS3 for ACRU (45\%) and PRSE (61\%), but differed only slightly from WS7 for LITU (overall $p=0.012$, ANOVA). The difference between watersheds for ACRU and PRSE resulted from a combination of lower $\mathrm{N}$ concentrations in green leaves (Fig. 2) and lower resorption proficiency (Fig. 3, bottom; discussed in the following paragraph).

Partly because green-leaf nutrient concentrations are sensitive to environmental variation, Killingbeck (1996) has argued that resorption proficiency, the concentration of a given nutrient in senesced leaves, may be a more definitive measure of resorption success than is resorption efficiency. In WS7, ACRU demonstrated substantially more proficient $\mathrm{N}$ resorption (i.e., lower $\mathrm{N}$ concentration in senesced leaves, $0.54 \%)$ than either LITU $(0.77 \%)$ or PRSE (0.78\%; Fig. 3, bottom; $p=0.070$, overall ANOVA among species). Lower mean proficiency was exhibited by all species in WS3 (ACRU, 0.77\%; LITU, 0.81\%; PRSE, 0.92\%; $p=0.049$, overall ANOVA between watersheds). Because, by definition, lower resorption proficiency results in higher $\mathrm{N}$ concentrations in senesced leaves, it is likely that the altered plant nutrient dynamics evident in WS3 will have important ecosystem-level implications if continued over the long term, the resultant changes in litter quality accelerating rates of $\mathrm{N}$ return to the soil, exacerbating $\mathrm{N}$ inputs from atmospheric $\mathrm{N}$ deposition. In addition, the interspecific differences in response evident here would likely result in altered species composition over time.

\section{Stem diameter growth}

Mean stem diameter (dbh) growth between 1999 and 2001 averaged $37 \%$ lower on WS3 for all three species taken together (Fig. 4; $p=0.036$, ANOVA). There was a strong, positive correlation between $\mathrm{N}$ resorption efficiency in 2001 and stem growth in 1999-2001 in WS7 within each species (Fig. 5; $p=0.015$, ANOVA for all species combined). In WS3, this relationship was negative and not significant ( $p=$ 0.841 ). Although it cannot be determined with any certainty, two lines of evidence suggest that the relationship in WS7 between stem growth and resorption may be a causal one. A number of studies have shown that nutrient investment in spring growth often derives primarily from nutrients stored by resorption in the previous season (Ryan and Bormann 1982; May and Killingbeck 1992; Millard 1996; Lal et al. 2001). In addition, May and Killingbeck (1992) prevented resorption in black scrub oak (Quercus ilicifolia Wangenh.) by defoliation immediately prior to senescence, resulting in significant reduction in stem growth and reproduction. In the present study, a causal relationship between resorption and stem growth may operate in WS7 but seems to have been uncoupled in WS3, where both resorption and stem growth declined together.

Magill et al. (2000) found increased radial growth in hardwoods, but decreased growth in pines after 9 years of fertilization with $150 \mathrm{~kg} \mathrm{~N} \cdot \mathrm{ha}^{-1} \cdot \mathrm{year}^{-1}$ at Harvard Forest in Massachusetts, USA. Similarly, Elvir et al. (2003) reported significantly greater growth in sugar maple but not in red spruce after 10 years of fertilization at $25 \mathrm{~kg} \cdot \mathrm{ha}^{-1} \cdot \mathrm{year}^{-1}$ at Bear Brook Watershed in Maine, USA. In a recent review, Emmett (1999) found few examples of decreasing stem 
growth in response to $\mathrm{N}$ fertilization, and then only at fertilization levels exceeding $60 \mathrm{~kg} \mathrm{~N} \cdot \mathrm{ha}^{-1} \cdot$ year $^{-1}$. Our results are unusual in that there was a measurable decline in growth of deciduous trees in response to a fertilization rate of $35 \mathrm{~kg} \cdot \mathrm{ha}^{-1} \cdot \mathrm{year}^{-1}$. The contrast in growth between WS3 and WS7 may represent a situation similar to that observed by Nellemann and Thomsen (2001) in Norwegian spruce forests, wherein increased atmospheric deposition of $\mathrm{N}$ and sulfur from industrial sources correlated with an initial increase in stem growth, but continued deposition led to significant growth declines.

\section{Synthesis}

Of the three study species, ACRU diverged most strongly from responses expected on the basis of previous studies. This is evident in (i) ACRU's lack of a positive relationship between foliar $\mathrm{N}$ concentration and soil $\mathrm{NO}_{3}-\mathrm{N}$ concentration in 2001 (Fig. 1), (ii) the strong decline in foliar $\mathrm{N}$ concentration and N/P ratio for ACRU in WS3 between 1992 and 2001 (Fig. 2), (iii) the stronger (relative to LITU and PRSE) reduction of resorption efficiency and proficiency in ACRU in WS3 (Fig. 3), and (iv) the greater reduction of stem diameter growth in ACRU in WS3 (Fig. 4). While we recognize that these differences could partially be attributed to the low replication that we were able to employ in the 2000-2001 sampling period $(N=3$ for each species in each watershed), correlative evidence suggests that at least the overall trends are likely to be real: The decline in foliar $\mathrm{N}$ that we observed for ACRU in the more recent data is consistent with the pattern of decline between 1992 and 1997 , when more individuals were sampled $(N=20$ and $N=5$, respectively). The depression of $\mathrm{N}$ resorption in ACRU was also evident (although less pronounced) in PRSE, and both of these species exhibited similar trends in foliar N/P ratios. Furthermore, reduced mean stem diameter growth in WS3 characterized all three species, although here again the difference was more substantial for ACRU.

Considered alone, a decrease in $\mathrm{N}$ resorption might be interpreted as an inconsequential reduction in use efficiency for a nutrient that is available in excess of need. However, coupled with reduced stem growth, it seems more likely that declining resorption signifies a disruption of normal senescence physiology in ACRU and, perhaps to a lesser extent, in PRSE. Interspecific divergence in plant nutrient and growth responses may therefore represent differential sensitivity to the changes in soil chemistry that are associated with chronically elevated $\mathrm{N}$ deposition, and may imply eventual changes in community composition in this mixed-deciduous forest.

Additional research is necessary to test these trends more rigorously. In addition to better replication in soil and foliar sampling, a broader suite of potentially interacting nutrients needs to be considered to study possible interactions among them in both soil availability and plant uptake. In addition, two of the long-term concerns in N-saturation research are the potential for reduced forest productivity and for substantial changes in community composition. The former could be assessed using increment cores, the latter by continued resampling of vegetation. The limitations imposed by the pseudoreplication problem (see Materials and methods section) will necessitate meta-analysis (Gurevitch and Hedges 1999; Osenberg et al. 1999), combining data from FEF and other long-term watershed-level experiments involving $\mathrm{N}$ additions. Unfortunately, differences in initial conditions (topography, soil, community composition and structure, climate, land-use history) and in experimental design complicate such analyses.

Because emergent changes resulting from fertilization of WS3 at FEF have accumulated in a very slow and nonlinear fashion, they are unpredictable from past patterns. As a result, studies of this nature substantiate the tremendous importance of continued long-term ecological monitoring and field experimentation.

\section{Acknowledgements}

This study was made possible by a grant to J.D.M. and F.S.G. from the USDA Cooperative State Research, Education, and Extension Service (award 99-35106-8399), for which we are grateful. We thank several reviewers whose comments contributed substantially to improving the manuscript, including the Associate Editor at the Canadian Journal of Forest Research, two anonymous reviewers, and Keith Killingbeck (University of Rhode Island). The authors also thank Doug Owens and his crew of foresters at the Fernow Experimental Forest for assistance in shotgun sampling of foliage.

\section{References}

Aber, J., McDowell, W., Nadelhoffer, K., Magill, A., Berntson, G., Kamakea, M. et al. 1998. Nitrogen saturation in temperate forest ecosystems. Bioscience, 48: 921-934.

Chapin, F.S., III, and Kedrowski, R.A. 1983. Seasonal changes in nitrogen and phosphorus fractions and autumn retranslocation in evergreen and deciduous taiga trees. Ecology, 64: 376-391.

Edwards, P.J., Kochenderfer, J.N., Coble, D.W., and Adams, M.B. 2002. Soil leachate responses during 10 years of induced wholewatershed acidification. Water Air Soil Pollut. 140: 99-118.

Elvir, J.A., Wiersma, G.B., White, A.S., and Fernandez, I.J. 2003. Effects of chronic ammonium sulfate treatment on basal area increment in red spruce and sugar maple at the Bear Brook Watershed in Maine. Can. J. For. Res. 33: 862-869.

Emmett, B.A. 1999. The impact of nitrogen on forest soils and feedbacks on tree growth. Water Air Soil Pollut. 116: 65-74.

Fenn, M.E., Poth, M.A., Aber, J.D., Baron, J.S., Bormann, B.T., Johnson, D.W. et al. 1998. Nitrogen excess in North American ecosystems: predisposing factors, ecosystem responses, and management strategies. Ecol. Appl. 8: 706-733.

Fernandez, I.J., Rustad, L.E., Norton, S.A., Kahl, J.S., and Cosby, B.J. 2003. Experimental acidification causes soil base-cation depletion at the Bear Brook Watershed in Maine. Soil Sci. Soc. Am. J. 67: 1909-1919.

Gilliam, F.S., Turrill, N.L., Aulick, S.D., Evans, D.K., and Adams, M.B. 1994. Herbaceous layer and soil response to experimental acidification in a central Appalachian hardwood forest. J. Environ. Qual. 23: 835-844.

Gilliam, F.S., Adams, M.B., and Yurish, B.M. 1996. Ecosystem nutrient responses to chronic nitrogen inputs at Fernow Experimental Forest, West Virginia. Can. J. For. Res. 26: 196-205.

Gilliam, F.S., Yurish, B.M., and Adams, M.B. 2001. Temporal and spatial variation of nitrogen transformations in nitrogensaturated soils of a central Appalachian hardwood forest. Can. J. For. Res. 31: 1768-1785. 
Gurevitch, J., and Hedges, L.V. 1999. Statistical issues in ecological meta-analysis. Ecology, 80: 1142-1149.

Hurlbert, S.H. 1984. Pseudoreplication and the design of ecological field experiments. Ecol. Monogr. 54: 187-211.

Hutchinson, T.C., Watmough, S.A., Sager, E.P.S., and Karagatzides, J.D. 1998. Effects of excess nitrogen deposition and soil acidification on sugar maple (Acer saccharum) in Ontario, Canada: an experimental study. Can. J. For. Res. 28: 299-310.

Killingbeck, K.T. 1996. Nutrients in senesced leaves: keys to the search for potential resorption and resorption proficiency. Ecology, 77: 1716-1727.

Koerselman, W., and Meuleman, A.F.M. 1996. The vegetation N:P ratio: a new tool to detect the nature of nutrient limitation. J. Appl. Ecol. 33: 1441-1450.

Lal, C.B., Annapurna, C., Raghubanshi, A.S., and Singh, J.S. 2001. Foliar demand and resource economy of nutrients in dry tropical forest species. J. Veg. Sci. 12: 5-14.

Magill, A.H., Aber, J.D., Berntson, G.M., McDowell, W.H., Nadelhoffer, K.J., Melillo, J.M., and Steudler, P. 2000. Longterm nitrogen additions and nitrogen saturation in two temperate forests. Ecosystems, 3: 238-253.

Matson, P., Lohse, K.A., and Hall, S.J. 2002. The globalization of nitrogen deposition: consequences for terrestrial ecosystems. Ambio, 31: 113-119.

May, J.D., and Killingbeck, K.T. 1992. Effects of preventing nutrient resorption on plant fitness and foliar nutrient dynamics. Ecology, 73: 1868-1878.

May, J.D., and Killingbeck, K.T. 1995. Effects of herbivore-induced nutrient stress on correlates of fitness and on nutrient resorption in scrub oak (Quercus ilicifolia). Can. J. For. Res. 25: 18581864.

Millard, P. 1996. Ecophysiology of the internal cycling of nitrogen for tree growth. Z. Pflanzenernaehr. Bodenkd. 159: 1-10.
Nellemann, C., and Thomsen, M.G. 2001. Long-term changes in forest growth: potential effects of nitrogen deposition and acidification. Water Air Soil Pollut. 128: 197-205.

Osenberg, C.W., Sarnelle, O., Cooper, S.D., and Holt, R.D. 1999. Resolving ecological questions through meta-analysis: goals, metrics, and models. Ecology, 80: 1105-1117.

Peterjohn, W.T., Adams, M.B., and Gilliam, F.S. 1996. Symptoms of nitrogen saturation in two central Appalachian hardwood forest ecosystems. Biogeochemistry, 35: 507-522.

Ryan, D.F., and Bormann, F.H. 1982. Nutrient resorption in northern hardwood forests. Bioscience, 32: 29-32.

Schaberg, P.G., Perkins, T.D., and McNulty, S.G. 1997. Effects of chronic low-level $\mathrm{N}$ additions on foliar elemental concentrations, morphology, and gas exchange of mature montane red spruce. Can. J. For. Res. 27: 1622-1629.

SPSS Inc. 2000. DeltaGraph 5.0 for Windows [computer program]. SPSS Inc., Chicago, Ill.

Stoddard, J.L. 1994. Long-term changes in watershed retention of nitrogen. In Environmental chemistry of lakes and reservoirs. Edited by Lawrence A. Baker. American Chemical Society, Washington, D.C. pp. 223-284.

SYSTAT Software, Inc. 2004. SYSTAT 11 [computer program]. SYSTAT Software, Inc., Richmond, Calif.

Tamm, C.O., Aronsson, A., and Popovic, B. 1995. Nitrogen saturation in a long-term forest experiment with annual additions of nitrogen. Water Air Soil Pollut. 85: 1683-1688.

Tessier, J.T., and Raynal, D.J. 2003. Use of nitrogen to phosphorus ratios in plant tissue as an indicator of nutrient limitation and nitrogen saturation. J. Appl. Ecol. 40: 523-534.

Van Heerwaarden, L.M., Toet, S., and Aerts, R. 2003. Nitrogen and phosphorus resorption efficiency and proficiency in six subarctic bog species after 4 years of nitrogen fertilization. J. Ecol. 91: $1060-1070$. 